\title{
A New Strategy to Stabilize Oxytocin in Aqueous Solutions: I. The Effects of Divalent Metal Ions and Citrate Buffer
}

\author{
Christina Avanti, ${ }^{1,5}$ Jean-Pierre Amorij, ${ }^{1}$ Dewi Setyaningsih, ${ }^{1}$ Andrea Hawe, ${ }^{2}$ Wim Jiskoot, ${ }^{2}$ Jan Visser, ${ }^{3}$ \\ Alexej Kedrov, ${ }^{4}$ Arnold J. M. Driessen, ${ }^{4}$ Wouter L. J. Hinrichs, ${ }^{1}$ and Henderik W. Frijlink ${ }^{1}$
}

\begin{abstract}
Received 24 December 2010; accepted 1 March 2011; published online 30 March 2011
Abstract. In the current study, the effect of metal ions in combination with buffers (citrate, acetate, $\mathrm{pH} 4.5$ ) on the stability of aqueous solutions of oxytocin was investigated. Both monovalent metal ions $\left(\mathrm{Na}^{+}\right.$and $\left.\mathrm{K}^{+}\right)$and divalent metal ions $\left(\mathrm{Ca}^{2+}, \mathrm{Mg}^{2+}\right.$, and $\left.\mathrm{Zn}^{2+}\right)$ were tested all as chloride salts. The effect of combinations of buffers and metal ions on the stability of aqueous oxytocin solutions was determined by RP-HPLC and HP-SEC after 4 weeks of storage at either $4^{\circ} \mathrm{C}$ or $55^{\circ} \mathrm{C}$. Addition of sodium or potassium ions to acetate- or citrate-buffered solutions did not increase stability, nor did the addition of divalent metal ions to acetate buffer. However, the stability of aqueous oxytocin in aqueous formulations was improved in the presence of 5 and $10 \mathrm{mM}$ citrate buffer in combination with at least $2 \mathrm{mM} \mathrm{CaCl}_{2}$, $\mathrm{MgCl}_{2}$, or $\mathrm{ZnCl}_{2}$ and depended on the divalent metal ion concentration. Isothermal titration calorimetric measurements were predictive for the stabilization effects observed during the stability study. Formulations in citrate buffer that had an improved stability displayed a strong interaction between oxytocin and $\mathrm{Ca}^{2+}, \mathrm{Mg}^{2+}$, or $\mathrm{Zn}^{2+}$, while formulations in acetate buffer did not. In conclusion, our study shows that divalent metal ions in combination with citrate buffer strongly improved the stability of oxytocin in aqueous solutions.
\end{abstract}

KEY WORDS: citrate buffer; divalent metal ions; improved stability; oxytocin.

\section{INTRODUCTION}

According to the World Health Organization, half a million of women in Africa, Asia, and Latin America die each year due to problems during pregnancy and childbirth. At least $25 \%$ of those deaths can be attributed to bleeding after child birth (post-partum hemorrhage), mainly caused by failure of the uterus to contract adequately after child birth (atonicity) (1).

The preferred drug to prevent post-partum hemorrhage is oxytocin. Oxytocin is a cyclic nonapeptide hormone [sequence: cyclo $\left(\mathrm{Cys}^{1}-\mathrm{Tyr}^{2}-\mathrm{Ile}^{3}-\mathrm{Gln}^{4}-\mathrm{Asn}^{5}-\mathrm{Cys}^{6}\right.$, $-\mathrm{Pro}^{7}-\mathrm{Leu}^{8}$ Gly $\left.{ }^{9}-\mathrm{NH} 2\right)$ ], which is naturally produced in the hypothalamus. It is involved primarily in uterine contraction and stimulation of milk release from the mammary tissue (2). Oxytocin, which is currently available in synthetic form (3),

\footnotetext{
${ }^{1}$ Department of Pharmaceutical Technology and Biopharmacy, University of Groningen, Antonius Deusinglaan 1, 9713 AV, Groningen, The Netherlands.

${ }^{2}$ Division of Drug Delivery Technology, Leiden/Amsterdam Center for Drug Research, Leiden University, Leiden, The Netherlands.

${ }^{3}$ Department of Pharmacokinetics, Toxicology, and Targeting, University of Groningen, Groningen, The Netherlands.

${ }^{4}$ Department of Molecular Microbiology, University of Groningen, Nijenborgh 7, 9747 AG, Groningen, The Netherlands.

${ }^{5}$ To whom correspondence should be addressed. (e-mail: c.avanti@ rug.nl)
}

has been widely used for indications such as induction of labor, augmentation of labor, post-partum hemorrhage, or uterine atony, and also for other indications such as diabetes insipidus and vasodilatory shock. Reported additional functions for oxytocin include an antiduretic effect and blood vessel contraction $(2,4,5)$.

Unfortunately, oxytocin preparations are highly unstable at elevated temperatures, which is an issue particularly in tropical countries (6). Stability studies conducted by Groot et al. (6) have shown that injectable oxytocin formulations are rapidly degraded as the storage temperature rises to $30^{\circ} \mathrm{C}$ or higher. Oxytocic tablets for oral administration (ergometrine, ethylergometrine, oxytocin, and desamino-oxytocin) are also not stable under simulated tropical conditions. Because of its poor stability at elevated temperatures, the use of oxytocin in many developing countries is limited. Thus, there is a clear need for a heat-stable oxytocin formulation, preferably an aqueous injectable solution, with improved thermal stability.

One way to effectively improve stability of several peptides in aqueous solution is using metal salts in combination with a suitable buffer (7). To investigate the effect of metal ions in buffered solutions on the stability of oxytocin, we screened various combinations of unbuffered and buffered solutions with monovalent or divalent metal ions. Hawe et al. (8) observed that the degradation of oxytocin strongly depends on the $\mathrm{pH}$ of the formulation, with the highest stability at $\mathrm{pH}$ 4.5. Therefore, all formulations will be set to $\mathrm{pH}$ 4.5. The purpose of this study is to investigate whether 
specific combinations of buffer and metal ions can stabilize oxytocin.

\section{MATERIALS AND METHOD}

\section{Materials}

The following materials were used in this study: oxytocin monoacetate powder (Diosynth, Oss, The Netherlands), citric acid, calcium chloride (Riedel-de Haen, Seelze, Germany), acetic acid, magnesium chloride, zinc chloride (Fluka, Steinheim, Germany), sodium hydroxide, sodium chloride, potassium chloride, sodium dihydrogen phosphate dihydrate, acetonitrile, formic acid (Merck, Darmstadt, Germany) and Baxter Viavlo Ringer's lactate solution for intravenous infusion (Baxter, Utrecht, The Netherlands).

\section{Formulation and Stability Study}

Oxytocin was formulated at a concentration of $0.1 \mathrm{mg} /$ $\mathrm{ml}$ in citrate $(5$ or $10 \mathrm{mM})$ or acetate $(10 \mathrm{mM})$ buffer at $\mathrm{pH} 4.5$ ( $\mathrm{pH}$ adjusted with sodium hydroxide) with different additions of metal ions. $\mathrm{pH}$ samples were controlled and remained within $\pm 0.1 \mathrm{pH}$ units during the stability study. The initial concentration of oxytocin was determined using UV spectrophotometry (9) at $280 \mathrm{~nm}$ with an extinction coefficient of $1.52 \mathrm{ml} \mathrm{mg}^{-1} \mathrm{~cm}^{-1}$. All metal ion solutions were prepared using their chloride salts at concentrations of $2,5,10$, and $50 \mathrm{mM}$. Control solutions were formulated in water ( $\mathrm{pH} 6.9 \pm 0.2$ ) and Ringers's lactate $(6.4 \pm 0.2)$. Ringers's lactate solution consists of $131 \mathrm{mM}$ sodium, $5 \mathrm{mM}$ potassium, $2 \mathrm{mM}$ calcium, $111 \mathrm{mM}$ chloride, and $29 \mathrm{mM}$ bicarbonate (as lactate). In this report, the following codes were used: First character(s) refer to the type of buffer or water; CB (citrate), AC (acetate), RL (Ringer's lactate), and W (water). Following digit(s) refer to buffer concentration in $\mathrm{mM}$, following character(s) to the type of metal ion, and last digit(s) to metal ion concentration in $\mathrm{mM}$. Thus, e.g., CB10Mg10 means $10 \mathrm{mM}$ citrate buffer $(\mathrm{pH} 4.5)$ and $10 \mathrm{mM} \mathrm{MgCl}_{2}$. After preparation, the solutions were stored in $6 \mathrm{R}$ glass type 1 vials for 4 weeks at either $4^{\circ} \mathrm{C}$ or $55^{\circ} \mathrm{C}$, and protected from light.

Based on the results of the screening study, oxytocin formulations in $10 \mathrm{mM}$ citrate buffer $\mathrm{pH} 4.5$ with 10 or $50 \mathrm{mM}$ divalent metal salts were selected for a longer period of stability study for 6 months at $40^{\circ} \mathrm{C}$ according to $\mathrm{ICH}$ guidelines for long-term and accelerated stability study for climatic zone III and IV (10).

\section{Reversed-Phase High-Performance Liquid Chromatography}

The recovery of oxytocin (remaining oxytocin as percentage of initial amount) was determined by RP-HPLC. RPHPLC was performed according to the procedure described by Hawe et al. (8) An Alltima C-18 RP column with $5 \mu \mathrm{m}$ particle size, inner diameter of $4.6 \mathrm{~mm}$, and length of $150 \mathrm{~mm}$ (Alltech, Ridderkerk, Netherlands), a Waters (Millipore) 680 Automated Gradient Controller, two Waters 510 HPLC pumps, a Waters 717 Plus Autosampler, and a Waters 486
Tunable Absorbance UV Detector were used. Samples of $20 \mu \mathrm{l}$ were injected and the separation was carried out at a flow rate of $1.0 \mathrm{ml} / \mathrm{min}$ and UV detection at $220 \mathrm{~nm}$. Samples were eluted using $15 \%(v / v)$ acetonitrile in $65 \mathrm{mM}$ phosphate buffer $\mathrm{pH} 5.0$ as solvent $\mathrm{A}$ and $60 \%(\mathrm{v} / \mathrm{v})$ acetonitrile in $65 \mathrm{mM}$ phosphate buffer $\mathrm{pH} 5.0$ as solvent $\mathrm{B}$. The acetonitrile concentration was linearly increased from $15 \%$ at the beginning, to $20 \%$ at $10 \mathrm{~min}$, to $30 \%$ at $20 \mathrm{~min}$, and finally to $60 \%$ at $25 \mathrm{~min}$.

\section{Size Exclusion HPLC}

The fraction of monomeric oxytocin (percentage of total remaining oxytocin) was assessed by Size Exclusion HPLC (HP-SEC). HP-SEC was carried out using a Superdex peptide 10/300 GL column (GE Healthcare Inc., Brussels, Belgium) on an isocratic HPLC system, according to the method previously reported by Hawe et al. (8). A Waters 510 pump, a Waters 717 plus auto sampler, a Waters 474 Scanning Fluorescence Detector and Waters 484 Tunable Absorbance Detector (Waters, Milford Massachusetts, USA) were used. Samples of $50 \mu \mathrm{l}$ were injected, and separation was performed at a flow rate of $1 \mathrm{ml} / \mathrm{min}$. Peaks were detected by UV absorption at $274 \mathrm{~nm}$, as well as fluorescence detection at excitation wavelength of $274 \mathrm{~nm}$ and emission wavelength of $310 \mathrm{~nm}$. The mobile phase consisted of $30 \%$ acetonitrile and $70 \% 0.04 \mathrm{M}$ formic acid.

\section{Isothermal Titration Calorimetry}

Isothermal titration calorimetry (ITC) was used to investigate the interaction between oxytocin and divalent metal ions in the presence of citrate buffer and acetate buffer. Microcalorimetric titrations of divalent metal ions to oxytocin were conducted by using a MicroCal ITC 200 Microcalorimeter (Northampton, MA 01060 USA). A solution of $300 \mu \mathrm{L}$ of $5 \mathrm{mM}$ oxytocin in $10 \mathrm{mM}$ of either citrate or acetate $\mathrm{pH} 4.5$ was placed in the sample cell, while $30 \mu \mathrm{L}$ of $125 \mathrm{mM}$ divalent metal chloride either calcium, magnesium, or zinc in $10 \mathrm{mM}$ citrate or acetate buffer $\mathrm{pH} 4.5$ was placed in the syringe. The reference cell contained $300 \mu \mathrm{L}$ of the corresponding buffer. Experiments were performed at $55^{\circ} \mathrm{C}$. Automated titrations were conducted up to a divalent metal ion/oxytocin molar ratio of $5: 1$. The effective heat of the peptide-metal ion interaction upon each titration step was corrected for dilution and mixing effects, as measured by titrating the divalent metal ion solution into buffer and by titrating buffer into oxytocin solution. To investigate the possibility of oxytocin or metal ion binding to the buffer components, control experiments were performed in water. The heats of bimolecular interactions were obtained by integrating the peak following each injection. All measurements were performed in triplicate.

ITC data were analyzed by using the ITC non-linear curve fitting functions for one or two binding sites from MicroCal Origin 7.0 software (MicroCal Software, Inc.). The calculated curve was determined by the best-fit parameter, which was used to determine the molar enthalpy change for binding and the corresponding association constant, $\mathrm{K}_{\mathrm{a}}$. The molar free energy of binding $\Delta \mathrm{G}^{\circ}$ and the molar entropy 
change $\Delta S^{\circ}$ were derived from the fundamental equations of thermodynamics $\Delta \mathrm{G}^{\circ}=-\mathrm{RT} \ln \mathrm{K}_{\mathrm{a}}$ and $\Delta \mathrm{G}^{\circ}=\Delta \mathrm{H}^{\circ}-\mathrm{T} \Delta \mathrm{S}^{\circ}$.

\section{RESULTS}

\section{Influence of Divalent Metal Ions on Oxytocin Stability in Unbuffered Solutions}

First, the effect of divalent metal ions on the stability of oxytocin in water without any buffer salt was investigated. RPHPLC results (Fig. 1a) showed that after 4 weeks of storage at $4^{\circ}$ C, oxytocin recovery was almost $100 \%$ in the presence of 2 $50 \mathrm{mM}$ zinc or $50 \mathrm{mM}$ calcium ions. No stabilizing effect was observed from the presence of magnesium $(2-50 \mathrm{mM})$ and calcium $(2-10 \mathrm{mM})$, where the recovery was reduced to about
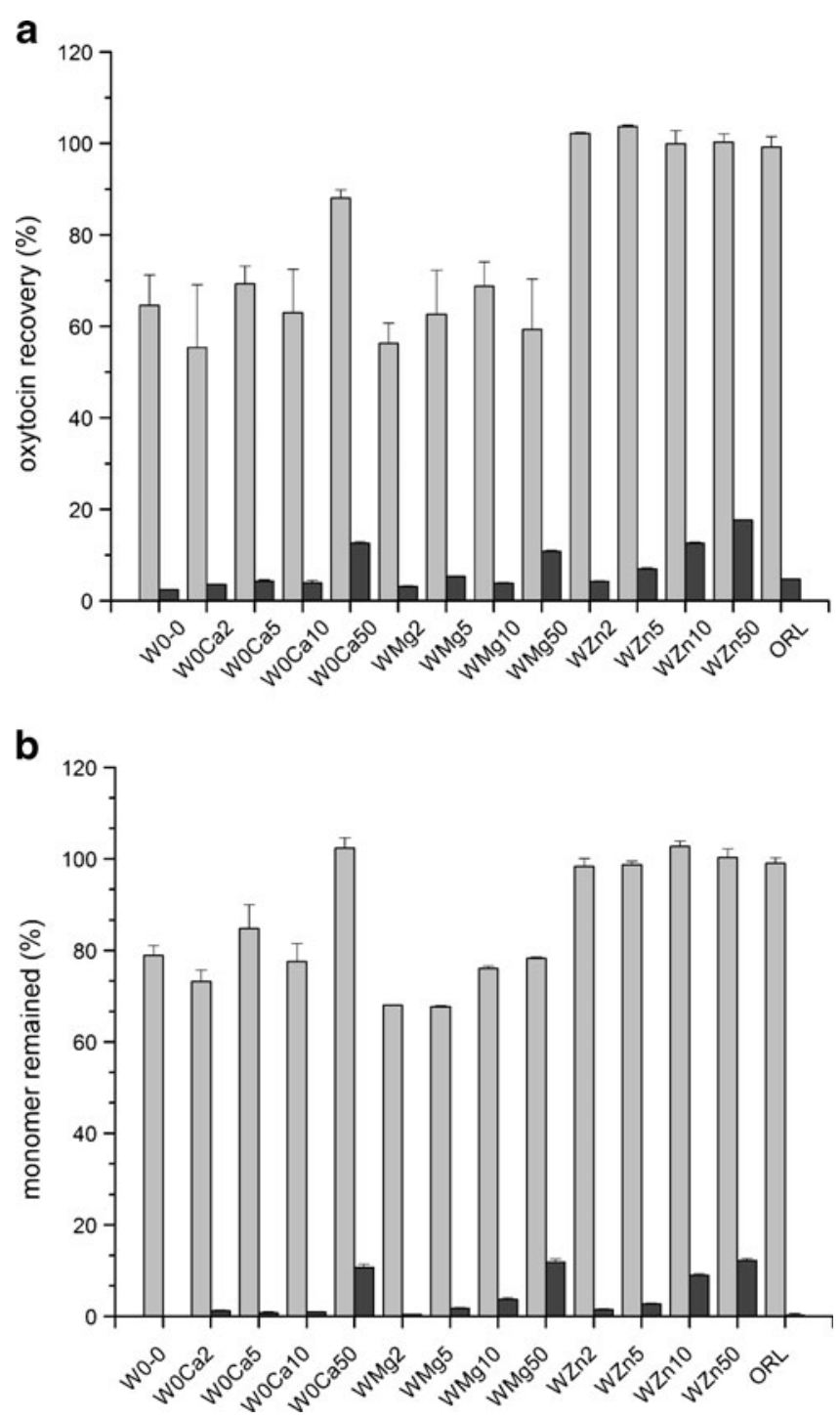

Fig. 1. Recovery of oxytocin in the presence of divalent metal ions in non-buffered, pure water stored for 4 weeks at $\mathrm{pH} 4.5$ and a temperature of $4^{\circ} \mathrm{C}$ (light gray bars) or $55^{\circ} \mathrm{C}$ (dark gray bars). The divalent metal ions $\left(\mathrm{Ca}^{2+}, \mathrm{Mg}^{2+}\right.$, and $\left.\mathrm{Zn}^{2+}\right)$ were used in concentrations of $2,5,10$, and $50 \mathrm{mM}$. a recovery determined by RP-HPLC. b oxytocin monomer recovery determined by HP-SEC. The results are depicted as averages of three independent measurements $\pm \mathrm{SD}$
$65 \%$, similar to levels found for oxytocin solutions in water. HPSEC results (Fig. 1b) showed a similar trend in the recovery of monomeric oxytocin. However, when the solutions were stored at $55^{\circ} \mathrm{C}$, both RP-HPLC and HP-SEC measurements showed substantial degradation of oxytocin after 4 weeks. These results demonstrate that divalent metal ions in non-buffered aqueous oxytocin formulations have only a limited stabilizing effect at elevated temperature.

\section{Oxytocin Stability in Buffered Solutions}

To determine the effect of buffer on stability, oxytocin was formulated in 5 and $10 \mathrm{mM}$ citrate buffer and $10 \mathrm{mM}$ acetate buffer. As a reference, the stability of oxytocin in pure water and in Ringer's lactate buffer was investigated. Figure 2a shows the oxytocin recovery in RP-HPLC after 4 weeks of storage either at $4^{\circ} \mathrm{C}$ or $55^{\circ} \mathrm{C}$ in the buffered solutions. Compared to pure water, the stability of oxytocin was substantially increased at $4^{\circ} \mathrm{C}$ in the presence of the buffer salts. After storage at $55^{\circ} \mathrm{C}$, the recovery of oxytocin after 4 weeks in citrate and acetate buffer was much higher as compared to water or Ringer's lactate solution. However, the recovery of oxytocin was still poor. In addition, only about $20 \%$ of oxytocin remained in its monomeric form after storage (Fig. 2b).

\section{Oxytocin Stability in Buffered Solutions Containing Monovalent Metal Ions}

To investigate the stability of oxytocin in the presence of a combination of buffer and monovalent metal ions, citrate and acetate buffer were used at a concentration of $10 \mathrm{mM}$, in combination with the monovalent metal ions, sodium and potassium, added at a concentration of 10 and $20 \mathrm{mM}$ (excluding sodium from the buffer component). The presence of monovalent metal ions had only a minor effect on the stability of oxytocin (stored at $55^{\circ} \mathrm{C}$ ). Although the oxytocin recovery was slightly improved compared to oxytocin in the presence of buffer alone, the maximum recovery of oxytocin was only $35 \%$ in $10 \mathrm{mM}$ acetate buffer with $10 \mathrm{mM}$ sodium chloride. In addition, only about $30 \%$ of oxytocin in this formulation remained monomeric (data not shown). These results clearly indicate that the presence of a combination of buffer and monovalent metal ions is not sufficient to substantially stabilize oxytocin in aqueous solution.

\section{Oxytocin Stability in Citrate-Buffered Solutions Containing Divalent Metal Ions}

To study the stability of oxytocin in the presence of citrate buffers and divalent metal ions, formulations containing 5 and $10 \mathrm{mM}$ citrate buffer in combination with divalent metal ions (calcium, magnesium, and zinc) added at concentrations of 2,5, 10 , or $50 \mathrm{mM}$ were used. The results of RP-HPLC and HP-SEC of formulations in $10 \mathrm{mM}$ citrate buffer are presented in Fig. 3a and $b$. The stability of oxytocin solutions was clearly improved when formulating them with citrate buffer in combination with calcium ions. The oxytocin stability increased with increasing calcium ion concentrations. The recovery of oxytocin and the remaining percentage of oxytocin monomers after 4 weeks of storage at $55^{\circ} \mathrm{C}$ were increased up to almost $80 \%$ in the presence of $50 \mathrm{mM}$ calcium. 

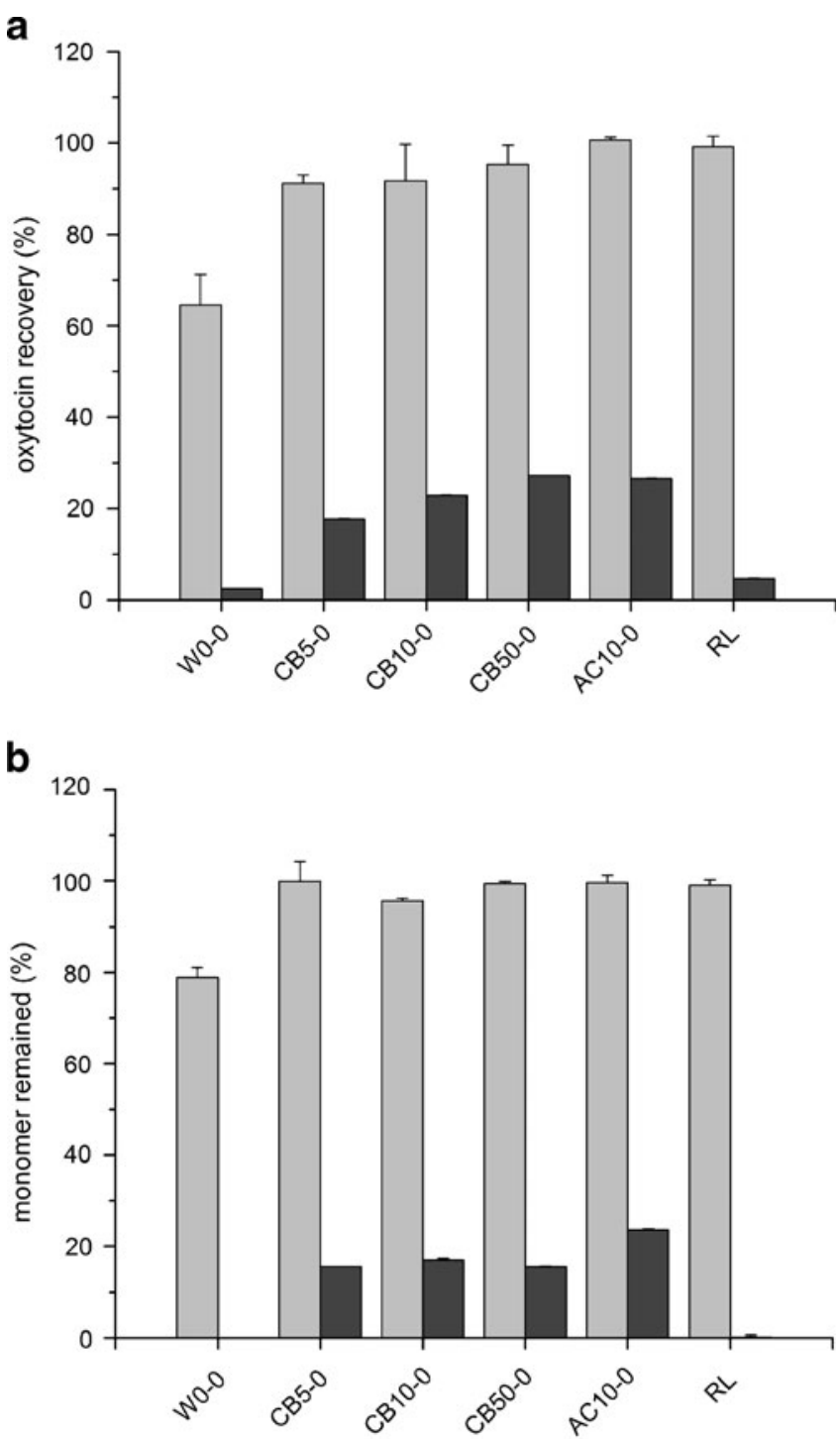

Fig. 2. Recovery of oxytocin in pure water, with or without a buffer. Citrate buffer at a concentration of 5,10 , or $50 \mathrm{mM}$, acetate buffer at a concentration of $10 \mathrm{mM}$, or Ringer's lactate solution were used. The formulations contained no metal ions and were stored for 4 weeks at $\mathrm{pH} 4.5$ or 6.4 for Ringer's lactate solution at a temperature of $4^{\circ} \mathrm{C}$ (light gray bars) or $55^{\circ} \mathrm{C}$ (dark gray bars). a recovery determined by RP-HPLC. b oxytocin monomer recovery determined by HP-SEC. The results are depicted as averages of three independent measurements \pm SD

Similar results were obtained for the combination of citrate with magnesium. The degradation of oxytocin in citrate buffer at 5 and $10 \mathrm{mM}$ decreased with an increasing concentration of magnesium ions. Formulations with zinc ions in citrate buffer also preserved oxytocin during storage. These combinations exert even a stronger effect on oxytocin stability than combinations of citrate buffer and calcium or magnesium ions. Stability was strongly improved at zinc concentrations as low as 2 or $5 \mathrm{mM}$. Both oxytocin recovery (RP-HPLC) and the monomeric oxytocin fraction (HP-SEC) were substantially higher (up to $90 \%$ ) in the presence of $10 \mathrm{mM}$ zinc ions (CB5Zn10) after storage for 4 weeks at $55^{\circ}$ C. When citrate buffer was used at a concentration of $5 \mathrm{mM}$, similar results were found (data not shown). a

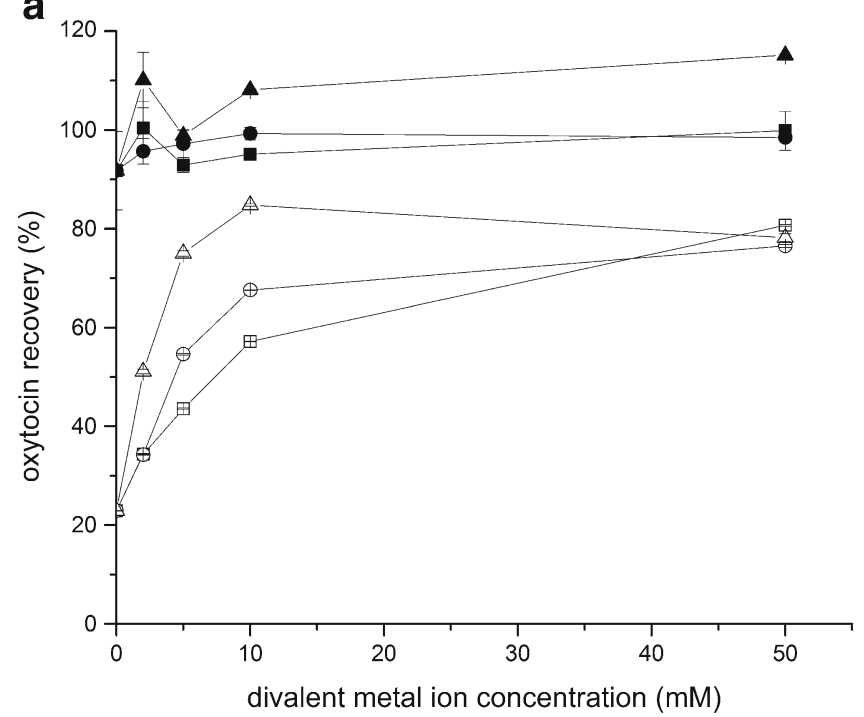

b

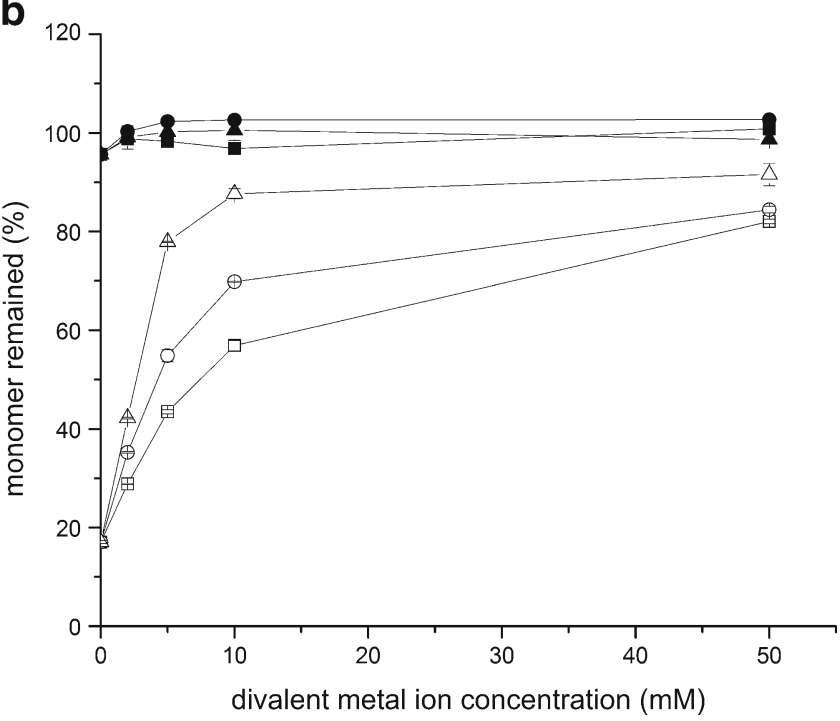

Fig. 3. Effect of $\mathrm{Ca}^{2+}$ (squares), $\mathrm{Mg}^{2+}$ (circles), and $\mathrm{Zn}^{2+}$ (triangles) concentration on the recovery of oxytocin in citrate buffer at the concentration of $10 \mathrm{mM}$ after 4 weeks of storage at either $4^{\circ} \mathrm{C}$ or $55^{\circ} \mathrm{C}$ and $\mathrm{pH}$ 4.5. Solid symbols denoted $4^{\circ} \mathrm{C}$ storage, while open symbols correspond to $55^{\circ} \mathrm{C}$. a recovery determined by RP-HPLC. b oxytocin monomer recovery determined by HP-SEC. The results are depicted as averages of three independent measurements $\pm \mathrm{SD}$

Beside citrate, we also carried out several further experiments to investigate whether divalent metal ions affect the stability in the presence of acetate buffer. Acetate buffer at a concentration of $10 \mathrm{mM}$ was used with and without calcium, magnesium, and zinc ions at various concentrations $(2,5,10,50 \mathrm{mM})$. The combination of these ions with acetate buffer was found to be less efficient in stabilizing oxytocin (data not shown).

\section{Long-term Stability of Oxytocin in Selected Formulations Containing Citrate and Divalent Metal Ions}

For the combination of citrate with $\mathrm{Ca}^{2+}, \mathrm{Zn}^{2+}$, and $\mathrm{Mg}^{2+}$, a long-term stability study for 6 months at $40^{\circ} \mathrm{C}$ was conducted. A 
temperature of $40^{\circ} \mathrm{C}$ was chosen to simulate tropical conditions $(10,11)$. The long-term stability study at $40^{\circ} \mathrm{C}$ clearly demonstrates the synergistic stabilizing effect of citrate buffer and divalent metal ions. Even though the oxytocin recovery decreased gradually with time, the recovery of oxytocin (Fig. 4a) and the remaining percentage of oxytocin monomers (Fig. 4b) after 6 months storage at $40^{\circ} \mathrm{C}$ were increased up to $80 \%$ in the presence of $50 \mathrm{mM}$ calcium, and even higher (up to $90 \%$ ) in the presence of $50 \mathrm{mM}$ magnesium.

Formulations with $10 \mathrm{mM}$ zinc ions in citrate buffer exerted the same effect on oxytocin stability as combinations of citrate buffer and $50 \mathrm{mM}$ magnesium ions. This shows that zinc ions at lower concentrations have already a higher impact on increasing oxytocin stability compared with calcium or magnesium ions.

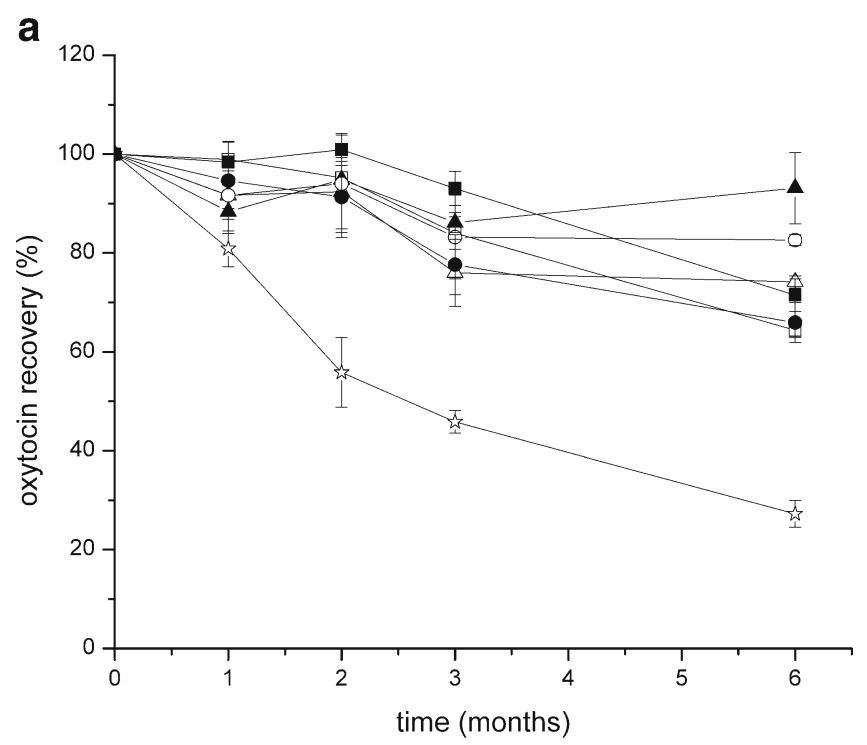

b

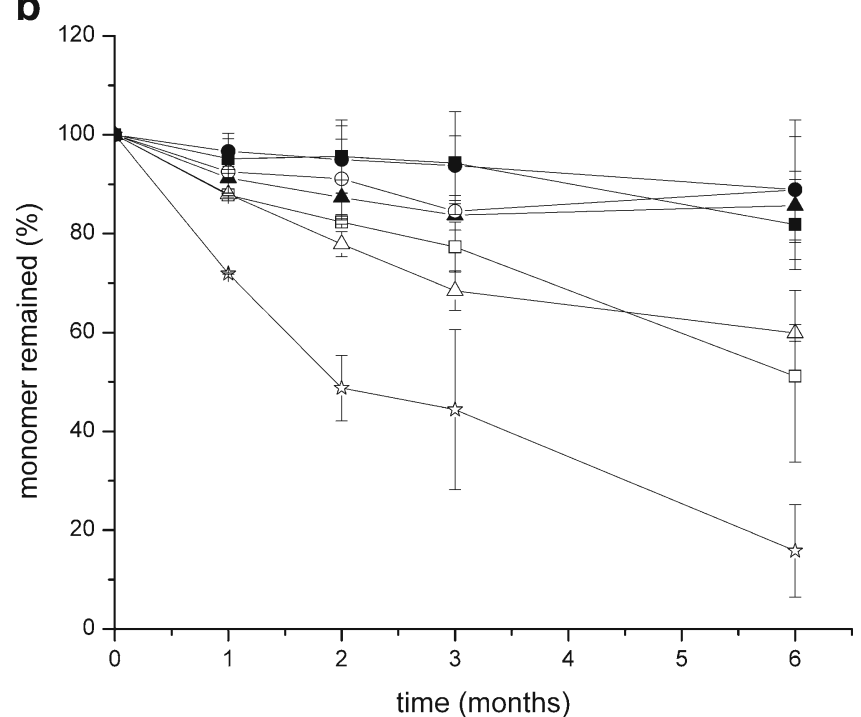

Fig. 4. Oxytocin recovery over time storage at $40^{\circ} \mathrm{C}$ and $\mathrm{pH} 4.5$ in the presence of $10 \mathrm{mM}$ citrate buffer, without (star) and with divalent metal ions. $\mathrm{Ca}^{2+}$ (square), $\mathrm{Mg}^{2+}$ (triangle), and $\mathrm{Zn}^{2+}$ (circle) were used in concentrations of $10 \mathrm{mM}$ (open symbols), and $50 \mathrm{mM}$ (solid symbols). a recovery determined by RP-HPLC. b oxytocin monomer recovery determined by HP-SEC. The results are depicted as averages of three independent measurements \pm SD
This result also confirms the short-term stability study that showed up to $90 \%$ remaining oxytocin in the presence of $10 \mathrm{mM}$ zinc ions after storage for 4 weeks at $55^{\circ} \mathrm{C}$.

\section{ITC to Study the Interaction Between Oxytocin and Divalent Metal Ions}

To examine the interaction between oxytocin and the metal ions, ITC experiments were carried out that are summarized in Table I. The titration of calcium ions into an oxytocin solution in citrate buffer resulted in an exothermic reaction (Fig. 5a) with a $\mathrm{K}_{\mathrm{a}}$ value of about $400 \mathrm{M}^{-1}$ and an apparent ion/oxytocin stoichiometry close to $4: 1$ (Table I). Remarkably, when titrating magnesium into oxytocin we observed heat absorption (Fig. 5a) and this endothermic reaction occurred with an identical apparent stochiometry (4:1) and a similar Ka value of about $200 \mathrm{M}^{-1}$ as with calcium ions. However, with magnesium ions the ITC trace was complex and showed an exothermic phase at magnesium concentrations below $5 \mathrm{mM}$. Due to the rapid saturation of this early phase-typically, within three injections-and the low enthalpy of the ion/oxytocin interaction it was not possible to quantitatively analyze the exothermic stage. To analyze the following endothermic phase we omitted the first 4-titration steps and fitted the remaining data using a single site model. A similar dual-phase response was observed for the zinc:oxytocin interaction (Fig. 5a, open triangles), but the exothermic and endothermic stages were well-resolved and suitable for the analysis using a two sites model (Table I). In contrast, in the presence of acetate buffer there was no measurable interaction between oxytocin and calcium, magnesium, or zinc ion (Fig. 5b).

\section{DISCUSSION}

Our study clearly demonstrates that the stability of oxytocin in aqueous formulations is greatly increased in citrate buffer in combination with divalent metal ions. The improved stability was found to be dependent on the divalent metal ions concentration.

The WHO reported that there is no loss of potency of oxytocin in injection preparation after 12 months refrigerated storage $\left(2-8^{\circ} \mathrm{C}\right)$. However, oxytocin lost $14 \%$ of its potency after 1 year at $30^{\circ} \mathrm{C}(12)$. In another study, the oxytocin concentration in Ringer's lactate solution was reduced by about $10 \%$ after 35 days storage at room temperature (near $23^{\circ} \mathrm{C}$ ) (13). From our observation Ringer's lactate solution was able to stabilize oxytocin in aqueous solution at low temperature $\left(4^{\circ} \mathrm{C}\right)$. However at a higher temperature $\left(55^{\circ} \mathrm{C}\right)$, the stability of Ringer's lactate solution was poorer than in the presence of citrate or acetate buffers. This result can be attributed to the $\mathrm{pH}$ and/or the amount of metal ions in solution. Oxytocin in Ringer's lactate solution has a $\mathrm{pH}$ of 6.4 and contains less than $2 \mathrm{mM}$ of divalent metal ions. Hawe et al. (8) observed that the degradation of oxytocin strongly depends on the $\mathrm{pH}$ of the formulation, with the highest stability at $\mathrm{pH} 4.5$. Therefore, a $\mathrm{pH}$ of 6.4 might have caused an increased rate of decomposition. However, formulating oxytocin in acetate buffer at $\mathrm{pH} 4.5$ only maintain approximately $30 \%$ oxytocin recovered after 1 month storage at $55^{\circ} \mathrm{C}$. 
Table I. Thermodynamics of Divalent Metal binding to Oxytocin as Determined by Isothermal Titration Calorimetry in $10 \mathrm{mM}$ Citrate Buffer

\begin{tabular}{llllll}
\hline Metal & Phase & $N($ sites $)$ & $K a\left(\mathrm{M}^{-1}\right)$ & $\Delta H^{\circ}\left(\mathrm{cal} \mathrm{mol}^{-1}\right)$ & $\Delta S^{\circ}(\mathrm{cal} / \mathrm{mol} / \mathrm{deg})$ \\
\hline $\mathrm{Ca}^{2+}$ & 1 & 0.26 & 400 & $-2,100$ & 5.6 \\
$\mathrm{Mg}^{2+}$ & 1 & n.d. & n.d. & $<0$ & n.d. \\
& 2 & 0.23 & 220 & 4,400 & 24 \\
$\mathrm{Zn}^{2+}$ & 1 & 0.78 & 2,700 & -800 & 13 \\
& 2 & 1.48 & 800 & 610 & 15 \\
\hline
\end{tabular}

The results are depicted as averages of three independent measurements with relative standard deviations below $10 \%$ n.d. not determined

The decomposition of oxytocin is mainly caused by deamidation, oxidation, hydrolysis, and dimerization $(7,8)$. Deamidation is likely to occur in $\operatorname{Gln}^{4}(14), \operatorname{Asn}^{5}(15)$, and Gly $^{9}(7,16)$. Under acidic condition ( $\mathrm{pH}$ below 3$)$, deamidation of $\mathrm{Asn}^{5}$ and $\mathrm{Gln}^{4}$ occur by direct hydrolysis (7). Oxidation might occur at $\operatorname{Tyr}^{2}$ (17) and Cys ${ }^{1,6}$ (18), whereas dimerization might occur due to thiol exchange in Cys $^{1,6}(19)$.

Although the specific mechanism has not been elucidate yet, the presence of sufficient amounts of divalent metal ions at pH 4.5 in citrate buffer, however, greatly improved the stability of oxytocin in aqueous solution. In previous studies, the interaction of oxytocin with calcium (20) and zinc (21) ions was investigated using NMR and nanoelectrospray mass spectrometry (MS). Those studies which were also supported with molecular modeling, showed that $\mathrm{Ca}^{2+}$ is coordinated by seven carbonyl oxygen atoms $\left(\mathrm{O}-\mathrm{Tyr}^{2}, \mathrm{O}-\mathrm{Ile}^{3}, \mathrm{O}-\mathrm{Gln}^{4}, \mathrm{O}-\mathrm{Asp}^{5}\right.$, $\mathrm{O}-\mathrm{Cys}^{6}, \mathrm{O}-\mathrm{Leu}^{8}$, and O-Gly ${ }^{9}$ ) which formed a more compact structure for the oxytocin- $\mathrm{Ca}^{2+}$ complex compared to free oxytocin (20). Whereas zinc ions formed an octahedral complex with six of the backbone carbonyl oxygen atoms $\left(\mathrm{O}-\mathrm{Tyr}^{2}, \mathrm{O}-\mathrm{Ile}^{3}\right.$, $\mathrm{O}-\mathrm{Gln}^{4}, \mathrm{O}^{-\mathrm{Cys}^{6}}{ }^{6}, \mathrm{O}-\mathrm{Leu}^{8}$, and O-Gly ${ }^{9}$ ) (21). It was suggested that in the presence of such divalent ions, the hydrophobic groups are situated inside the peptide keeping them away from water molecules. These conformational changes can increase the stability of oxytocin in aqueous medium as they will prevent dimerization and further aggregation by hydrophobic interactions among oxytocin molecules. Metal salts are often used to stabilize peptides or proteins by chelation or ionic interactions (22). Wang et al. examined the peptide (P66) stability in the presence of $\mathrm{ZnCl}_{2}, \mathrm{MgCl}_{2}$, and $\mathrm{CaCl}_{2}$ in non aqueous solution, and found that in the presence of $1 \mathrm{mM}$ $\mathrm{ZnCl}_{2}, \mathrm{P} 66$ was significantly stabilized. However in the aqueous solution (pure water), these ions did not show any stabilizing effect (22). In our experiments, the addition of calcium, magnesium, and zinc ions in combination with citrate buffer had a large impact on oxytocin stability in contrast to similar experiments in pure water or acetate buffer. This study suggests that there is a synergistic effect between citrate buffer and the divalent metal ions, possibly due to the protection of the disulfide bridge by complex formation of divalent metal ion and citrate with oxytocin which suppressed intermolecular reaction leading to tri/tetrasulfide formation as well as dimerization (unpublished data).

ITC is a sensitive method for studying the thermodynamics of binding events and quantifying binding reactions. When a

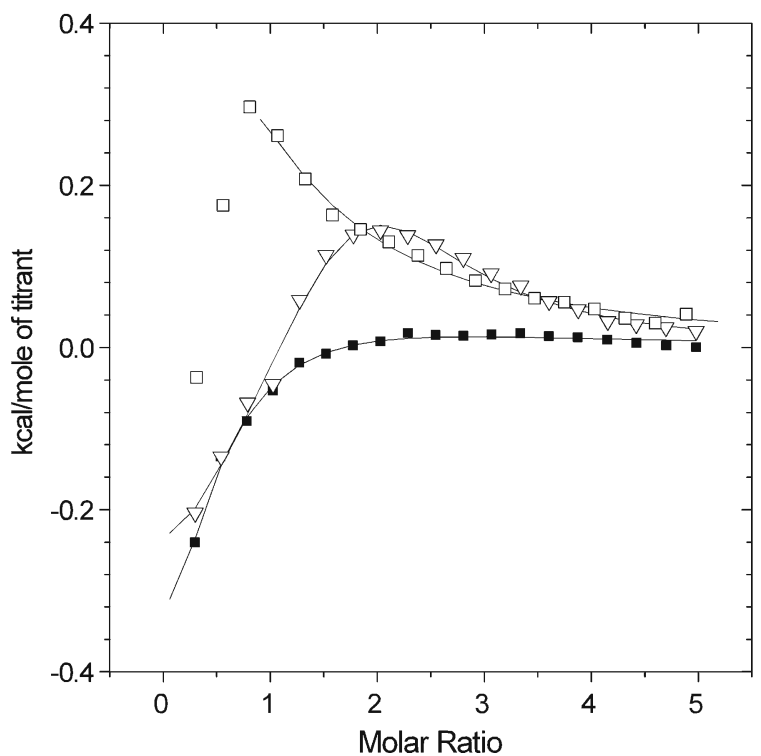

b

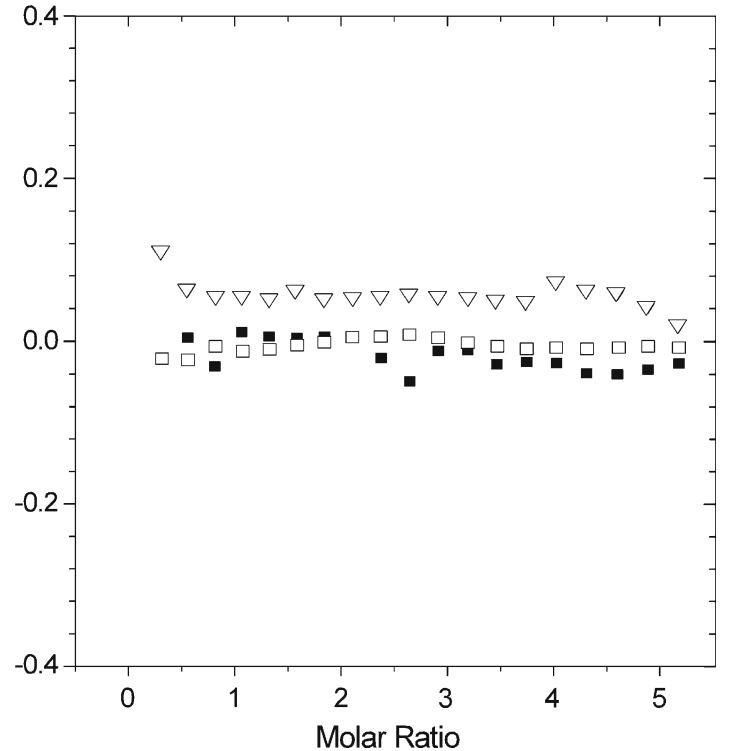

Fig. 5. Least squares fit of the data from calorimetric titration profiles of aliquots of $125 \mathrm{mM}$ divalent metal ions: $\mathrm{Ca}^{2+}$ (solid square), $\mathrm{Mg}^{2+}$ (open square), and $\mathrm{Zn}^{2+}$ (open triangle) into $5 \mathrm{mM}$ oxytocin in $10 \mathrm{mM}$ a citrate buffer and b acetate buffer $\mathrm{pH}$ 4.5. The heat absorbed per mol of titrant is plotted versus the ratio of the total concentration of divalent metal ions to the total concentration of oxytocin 
divalent metal ion are added to oxytocin, the ITC data indicate an interaction between oxytocin and $\mathrm{Ca}^{2+}, \mathrm{Mg}^{2+}$, or $\mathrm{Zn}^{2+}$ ions in the presence of citrate buffer. Both $\mathrm{Mg}^{2+}$ and $\mathrm{Zn}^{2+}$ ions demonstrated complex, dual-phase interaction profile, while a single phase was observed for $\mathrm{Ca}^{2+}$. Each interaction was entropy driven, while both exothermic and endothermic reactions were observed. It may be speculated that the solvation effect, i.e., release of structured water molecules plays a key role in binding, while the specific ion-oxytocin interaction further contributes to the complex stability. The latter is also predicted by molecular dynamic simulations $(20,21)$. Remarkably, no interaction between oxytocin and either of the tested ions was detected in the acetate buffer or deionized water. These observations underscore the role of a particular environment in the ion-oxytocin interaction and agree well with our findings on the peptide stability. Isothermal titration calorimetric measurements were predictive for the effects observed during the stability study.

In conclusion, this study shows that with a combination of divalent metal salts and citrate buffer, the stability of oxytocin in aqueous solution can be strongly improved. The increased stability of oxytocin aqueous formulations was achieved in the presence of citrate acid buffer and $2 \mathrm{mM}$ or more of the salts $\mathrm{CaCl}_{2}, \mathrm{MgCl}_{2}$, or $\mathrm{ZnCl}_{2}$. The oxytocin stability is further increased with increasing concentration of the divalent metals ions up to $50 \mathrm{mM}$. In combination with citrate buffer, $\mathrm{Zn}^{2+}$ has a superior stabilizing effect as compared with $\mathrm{Ca}^{2+}$ or $\mathrm{Mg}^{2+}$.

\section{ACKNOWLEDGMENTS}

The authors want to thank MSD Oss for providing oxytocin for the study. This study was performed within the framework of the Dutch Top Institute Pharma project: number D6-202.

Open Access This article is distributed under the terms of the Creative Commons Attribution Noncommercial License which permits any noncommercial use, distribution, and reproduction in any medium, provided the original author(s) and source are credited.

\section{REFERENCES}

1. Khan KS, Wojdyla D, Say L, Gulmezoglu AM, Van Look PF. WHO analysis of causes of maternal death: a systematic review. Lancet. 2006;367(9516):1066-74.

2. Ananthanarayanan VS, Brimble KS. Interaction of oxytocin with $\mathrm{Ca} 2+$ : I. CD and fluorescence spectral characterization and comparison with vasopressin. Biopolymers. 1996;40(5):433-43.

3. Bishop EH. Synthetic oxytocin; a clinical evaluation. Obstet Gynecol. 1958;11(3):290-4.

4. Conrad KP, Gellai M, North WG, Valtin H. Influence of oxytocin on renal hemodynamics and electrolyte and water excretion. Am J Physiol. 1986;251(2 Pt 2):F290-6.
5. Somlyo AV, Woo CY, Somlyo AP. Responses of nerve-free vessels to vasoactive amines and polypeptides. Am J Physiol. 1965;208:748-53.

6. Groot ANJA, Vree TB, Hogerzeil HV, Walker GJA. Stability of oral oxytocics in tropical climates: results of simulation studies on oral ergometrine, oral methylergometrine, buccal oxytocin and buccal desamino-oxytocin. Geneva: World Health Organization; 1994.

7. Manning MC, Chou DK, Murphy BM, Payne RW, Katayama DS. Stability of protein pharmaceuticals: an update. Pharm Res. 2010;27(4):544-75.

8. Hawe A, Poole R, Romeijn S, Kasper P, van der Heijden R, Jiskoot W. Towards heat-stable oxytocin formulations: analysis of degradation kinetics and identification of degradation products. Pharm Res. 2009;26(7):1679-88.

9. Gill SC, von Hippel PH. Calculation of protein extinction coefficients from amino acid sequence data. Anal Biochem. 1989;182(2):319-26.

10. International Conference on Harmonisation; Stability Data Package for Registration Applications in Climatic Zones III and IV; Stability Testing of New Drug Substances and Products; availability. Notice. ICH Technical Coordination, EMEA. 2003;68(225):65717-8

11. Grimm W. Extension of the International Conference on Harmonization Tripartite Guideline for Stability Testing of New Drug Substances and Products to countries of climatic zones III and IV. Drug Dev Ind Pharm. 1998;24(4):313-25.

12. Hogerzeil H.V. WGJA, De Goeje M.J. Stability of injectable oxytocics in topical climates.Results of field surveys and simulation studies on ergometrine, methylergometrine and oxytocin. Action Programme on Essential Drugs. 1993.

13. LA Trissel ZY, Douglass K, Kastango E. Extended Stability of Oxytocin in common infusion solution. Int $\mathrm{J}$ Pharm Compd. 2006;10:156-8.

14. Joshi AB, Sawai M, Kearney WR, Kirsch LE. Studies on the mechanism of aspartic acid cleavage and glutamine deamidation in the acidic degradation of glucagon. J Pharm Sci. 2005;94 (9):1912-27.

15. Yang H, Zubarev RA. Mass spectrometric analysis of asparagine deamidation and aspartate isomerization in polypeptides. Electrophoresis. 2010;31(11):1764-72.

16. Robinson NE. Protein deamidation. Proc Natl Acad Sci USA. 2002;99:5283-8.

17. Leeuwenburgh C, Rasmussen JE, Hsu FF, Mueller DM, Pennathur S, Heinecke JW. Mass spectrometric quantification of markers for protein oxidation by tyrosyl radical, copper, and hydroxyl radical in low density lipoprotein isolated from human atherosclerotic plaques. The Journal of Biological Chemistry. 1997;272(6):3520-6.

18. Fiser A, Simon I. Predicting the oxidation state of cysteines by multiple sequence alignment. Bioinformatics. 2000;16 (3):251-6.

19. Klingenberg M, Appel M. The uncoupling protein dimer can form a disulfide cross-link between the mobile C-terminal SH groups. Eur J Biochem. 1989;180(1):123-31.

20. Ananthanarayanan VS, Belciug MP, Zhorov BS. Interaction of oxytocin with $\mathrm{Ca} 2+$ : II. Proton magnetic resonance and molecular modeling studies of conformations of the hormone and its Ca2+ complex. Biopolymers. 1996;40(5):445-64.

21. Liu D, Seuthe AB, Ehrler OT, Zhang X, Wyttenbach T, Hsu JF, et al. Oxytocin-receptor binding: why divalent metals are essential. J Am Chem Soc. 2005;127(7):2024-5.

22. Wang W, Martin-Moe S, Pan C, Musza L, Wang YJ. Stabilization of a polypeptide in non-aqueous solvents. Int J Pharm. 2008;351 $(1-2): 1-7$. 